\title{
Performance of Annually Harvested Improved Turmeric (Curcuma longa L.) Cultivars Grown under Rainfed Conditions
}

\author{
Shakuntla Rahi*, D. S. Yadav, Pankaj Sood, Kavita Sharma and L. K. Sharma \\ CSKHPKV, Krishi Vigyan Kendra, Mandi Himachal Pradesh-175019, India \\ *Corresponding author
}

\section{A B S T R A C T}

\section{Keywords}

Extension gap, FLD, Technology gap, Technology index, Turmeric

Article Info

Accepted:

21 May 2020

Available Online:

10 June 2020
The study assessed the performance of annually harvested improved cultivars of turmeric (Curcuma longa L.) under rainfed conditions in Mandi district of Himachal Pradesh. A total of 64 front line demonstrations (FLDs) were conducted consecutively for two years (Kharif 2014 and Kharif 2015). Two annually harvested turmeric cultivars Palam Pitambar and Palam Lalima were demonstrated under the FLD programme with the recommended package of practices against the widely grown local strain 'SuketiHaldi' as farmer's practice. The study revealed that in demonstration plots rhizome yield of both varieties was significantly higher over the farmer's practice in all the years. Overall, $270.02 \mathrm{q} \mathrm{ha}^{-1}$ of rhizome yield with $38.85 \%$ increased production over farmer's practice and average net returns of Rs. 2,64,166 ha ${ }^{-1}$ was obtained under demonstration plot in pooled data. The technology index value of $16.92 \%$ showed the better performance of FLD's interventions and thus annually harvested cultivars exhibited great potential in boosting the turmeric productivity with wider adaptability in the region. The technology and extension gap based on pooled data for two years FLDs programme was 54.98 and $75.55 \mathrm{qha}^{-1}$ respectively emphasize the need to narrow down these gaps by deploying effective research and extension services.

\section{Introduction}

Turmeric (Curcuma longa L.) is one of the most important spice crops and India is the largest producer \&exporter in the world. India contributes about $80 \%$ of the world turmeric production and $60 \%$ of world export (Anonymous 2018). Indian turmeric is considered to be the best in the world because of its high curcumin content. This crop can be grown in diverse tropical conditions ranging from sea level to $1500 \mathrm{~m}$ elevation. The temperature range of $20-30^{\circ} \mathrm{c}$ with an annual rainfall of $1500 \mathrm{~mm}$ is ideal for its cultivation. Though it can be grown on different types of soil, but it thrives best in well-drained sandy or clay loam soils.

The tuberous rhizome or underground stems of turmeric have been used from antiquity as condiments, a dye, and as an aromatic stimulant in several medicines. Turmeric is also used as a coloring matter in drugs, confectionery, and food industries (Khan et 
al., 2014). Himachal Pradesh is one of the important hilly states of north-western (NW) Himalayas and the majority of the farmers are small and marginal. The cereal-based cropping systems are not remunerative to secure the livelihood of farmers. Further, despite various factors, monkey menace is a major problem faced by a large number of farmers compelling them to keep their land fallow. In such situations, turmeric cultivation can be a viable option for remunerative returns. Turmeric is grown mostly organic by default with no use of chemicals by farmers in Himachal Pradesh in general and Mandi district in particular. However, the productivity of this crop is quite low due to biennial local strains grown by the farmers.

Henceforth, KVK, Mandi Himachal Pradesh took initiative in this direction and introduced the annually harvested improved cultivars of turmeric through front line demonstrations (FLDs) in the district. Front line demonstrations (FLDs) are innovative extension methods for the transfer of technologies among the farmers and works on the principle of learning by doing and seeing by believing. Generally, any technology is not accepted as such in all respect and there always exists a gap between the recommended technology and adopted by the farmers. The identification of such gaps provides valuable information to planners, researchers, and extension workers to prepare guidelines for reducing these gaps. The technology and extension yield gaps have been identified in this paper and will be useful for framing up of strategies for enhancing turmeric acre age in the state.

\section{Materials and Methods}

The study was carried out by Krishi Vigyan Kendra, Mandi during kharif 2014 and 2015. A total of64 demonstrations covering 3.76 ha area were conducted in different villages of the district viz, Padhar, Tandu, Masheran, Jalahar and Pipli(Drang block), Kothi (Balh block), Kotali, Palliand Pandoh (Sadar block), Nalini (Sundernagar block) and Nahuali (Chauntra block).

All other steps like site and farmer selection, layout of demonstrations, etc. were followed as suggested by (Choudhary, 1999). FLD's were conducted along with full package and practices especially in monkey menaceareas under rainfed conditions.

Two annually harvested high yielding turmeric cultivars (Palam Pitamber and Palam Lalima) recommended by CSKHPKV, Palampur was demonstrated under FLDs while widely grown local strain 'SuketiHaldi' was taken as farmer's practice/check.

Planting was done during the second fortnight of May with a spacing of $30 \times 20 \mathrm{~cm}$. The data on rhizome yield under demonstration plot as well as the farmer's plot was collected and analyzed. Fisher's Least Significant Difference (LSD) test was employed to analyze the difference in mean rhizome yield between demonstration plot and farmer's plot, (Yadav et al., 2018).

Likewise, the increase in rhizome yield in the demonstration plot over farmers' practice was worked out as per the formula earlier used by various researchers (Choudhary et al., 2009; Yadav et al., 2018):

Yield increase over farmer's practice (YIOFP, $\%$ )
\[ =\frac{\text { Demonstration Plot Yield (DPY)- Farmer's slot Yield (FPY) }}{\text { Farmer's Plot Yield (FPY) }} \times 100 \]

Technology gap, extension gap and technology index was worked by the following formulae as earlier used by various researchers (Kadian et al., 1997; Samui et al., 2000; Yadav et al., 2018): 
Technology gap $\left(\mathrm{q} \mathrm{ha}^{-1}\right)=$ Potential Yield (PY) - Demonstration Plot Yield (DPY) The study further revealed that mean rhizome yield in demonstration plots was significantly Extension gap $\left(\mathrm{q} \mathrm{ha}^{-1}\right)=$ Demonstration Plot Yield (DPY) - Farmer's Plot Yield (PPY) higher in both varieties over the farmer's practice in all the years. Demonstration of

Technology Index (TI \%)

$$
=\frac{\text { Potential Yield (PY) - Demonstration Plot Yield (DPY) }}{\text { Potential Yield (PY) }} \times 100
$$

\section{Economic analysis of FLD's}

The standard formula was applied for calculating the gross and net returns as earlier used by various workers (Choudhary et al., 2009; Yadav et al., 2018).

\section{Results and Discussion}

\section{Rhizome yield under turmeric cultivars}

The performance of improved turmeric cultivars demonstrated under FLDs has been given in Table 1. Annually harvested turmeric cultivars Palam Pitambar and Palam Lalima was demonstrated under FLDs and compared with biennially harvested local "SuketiHaldi" under farmers practice.

The results revealed that turmeric cultivar Palam Pitambar provided the highest rhizome yield of $287.64 \mathrm{q} \mathrm{ha}^{-1}$ under the demonstration plot during kharif 2014 which was about 50\% higher than the farmer's practice. During kharif 2015, this cultivar provided the rhizome yield of $279.62 \mathrm{q} \mathrm{ha} \mathrm{h}^{-1}$ with additional yield advantage to the tune of about $42 \%$ over local practice. The study also revealed that Palam Lalima cultivar of turmeric provided rhizome yield of 256.89 and $254.65 \mathrm{q} \mathrm{ha}^{-1}$ with the increased rhizome yield of $33.92 \%$ and $28.70 \%$ over farmer's practice during kharif 2014 and kharif 2015 respectively. Overall, $270.02 \mathrm{q} \mathrm{ha}^{-1}$ of rhizome yield was obtained under the demonstration plot in pooled data which was $38.85 \%$ higher against farmer's practice. complete package under FLDs might be the reason for the superiority of these cultivars which otherwise was not followed under farmer's practice. The Similar results of yield enhancement of turmeric in front line demonstration have also been earlier reported by various workers (Barua and Tripathi, 2015; Mishra et al., 2015; Dubey et al., 2017; Kant et al., 2020).

\section{Economics of front line demonstrations}

The economic analysis of demonstrated technology under FLDs in comparison to farmer's practice presented in Table 2 revealed that the highest net returns of Rs.

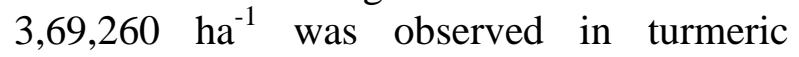
cultivar Palam Pitambar during kharif 2014 which was much higher than the farmer's practice. Turmeric cultivar Palam Lalima also provided a net return of Rs. 3,23,135 ha-1 during this season. During kharif 2015, these two varieties provided net returns of Rs. 1,94,620 and Rs. 1,69,650 ha $^{-1}$ respectively which was higher against farmer's practice (Table 2). The average net returns to the tune of Rs. 2,64,166 $\mathrm{ha}^{-1}$ was obtained under the demonstrated technology in pooled data of both cultivars. The higher net returns over the farmer's practice might be attributed to the adoption of improved technologies. Enhanced monetary returns through improved farm technology have also been earlier reported by various workers (Singh et al., 2006; Barua and Tripathi 2015; Mishra et al., 2015; Dubey et al., 2017; Kant et al., 2020).

\section{Technology and extension gap}

Results in Figure 1 shows that the technology gap ranged between 37.36 to $70.35 \mathrm{q} \mathrm{ha}^{-1}$ in annually harvested turmeric cultivars 
demonstrated under FLDs. The highest technology gap to the tune of 68.11-70.35 q $\mathrm{ha}^{-1}$ was observed in Palam Lalima during kharif 2014 and kharif 2015. Comparatively less technology gap (37.36-45.38 q ha-1) was observed in Palam Pitambar cultivar of turmeric during the seasons under study (Fig. 1). The overall technological gap based on pooled data for two years FLDs programme was $54.98 \mathrm{q} \mathrm{ha}^{-1}$.

The variations in the technology gap might be due to the variability in the soil fertility status, unfavorable agro-climatic conditions, and specific crop management problems thus require location-specific crop management measures to minimize these gaps. Earlier, various workers also reported technology gaps due to these factors in their respective studies (Choudhary, 2013; Kumar et al., 2015; Yadav et al., 2018).

While looking at the status of extension gaps in Fig. 1, the results revealed the decreasing trend of extension gaps in both cultivars of turmeric during the period under study. The extension gap ranged between 56.79 to 95.81 $\mathrm{q} \mathrm{ha}^{-1,}$ and Palam Pitambar cultivar of turmeric recorded the highest extension gap (81.76-95.81 $\mathrm{q} \mathrm{ha}^{-1}$ ) during both the seasons. The study also revealed that $\mathrm{Cv}$. Palam Lalima recorded $65.06 \mathrm{q} \mathrm{ha}^{-1}$ of extension gap during kharif 2014 followed by kharif 2015(56.79 $\left.\mathrm{q} \mathrm{ha}^{-1}\right)$. On an average extension gap under two consecutive years of the FLD programme was $75.55 \mathrm{qha}^{-1}$ (Fig. 1). Lack of awareness for the adoption of improved farm technologies by the farmers might be the reason for extension gaps and thus emphasized the need to put more effort to educate farmers through innovative extension methods to bridge these gaps. These results are also supported by the findings of Dubey et al., 2017 and Kant et al., 2020.

\section{Technology index}

The technology index presented in Fig. 2 showed an increasing trend over the years under study. The least technology index (11.50-13.96\%) was observed in the Palam Pitambar cultivar of turmeric during both the years. On the other hand, this index varied between 20.96-21.65\% for Palam Lalima. The lower value of the technology index indicates higher feasibility of the technology.

Table.1 Performance of improved turmeric cultivars demonstrated under FLDs in Mandi district of Himachal Pradesh

\begin{tabular}{|c|c|c|c|c|c|c|c|}
\hline \multirow{2}{*}{$\begin{array}{l}\text { Year/ } \\
\text { season }\end{array}$} & \multirow{2}{*}{$\begin{array}{c}\text { Variety } \\
\text { under } \\
\text { DP* }\end{array}$} & \multirow{2}{*}{$\begin{array}{l}\text { No. of } \\
\text { demo. }\end{array}$} & \multirow{2}{*}{$\begin{array}{c}\text { Area } \\
\text { (ha) }\end{array}$} & \multicolumn{2}{|c|}{ Rhizome Yield(q/ha)) } & \multirow[t]{2}{*}{$\mathbf{L S D}_{0.05}$} & \multirow[t]{2}{*}{$\%$ increase } \\
\hline & & & & DP* & $\mathbf{F P * *}$ & & \\
\hline $\begin{array}{l}\text { Kharif } \\
2014\end{array}$ & $\begin{array}{c}\text { Palam } \\
\text { Pitambar }\end{array}$ & 18 & 0.90 & 287.64 & 191.83 & 5.33 & 49.95 \\
\hline $\begin{array}{l}\text { Kharif } \\
2015\end{array}$ & $\begin{array}{c}\text { Palam } \\
\text { Pitambar }\end{array}$ & 14 & 0.98 & 279.62 & 197.86 & 5.95 & 41.32 \\
\hline $\begin{array}{l}\text { Kharif } \\
2014\end{array}$ & $\begin{array}{l}\text { Palam } \\
\text { Lalima }\end{array}$ & 18 & 0.90 & 256.89 & 191.83 & 7.69 & 33.92 \\
\hline $\begin{array}{l}\text { Kharif } \\
2015\end{array}$ & $\begin{array}{l}\text { Palam } \\
\text { Lalima }\end{array}$ & 14 & 0.98 & 254.65 & 197.86 & 9.66 & 28.70 \\
\hline $\begin{array}{l}\text { Pooled } \\
\text { data }\end{array}$ & & 64 & 3.76 & 270.02 & 194.47 & 5.01 & 38.85 \\
\hline
\end{tabular}

* DP: Demonstration plot; **FP: Farmers plot 
Table.2 Economic analysis of turmeric cultivars demonstrated under FLDs

\begin{tabular}{|l|l|c|c|c|c|c|c|c|c|}
\hline \multirow{2}{*}{$\begin{array}{l}\text { Year/ } \\
\text { season }\end{array}$} & $\begin{array}{l}\text { Turmeric } \\
\text { cultivars }\end{array}$ & \multicolumn{2}{|c|}{$\begin{array}{c}\text { Gross Cost } \\
\text { (Rs/ha) }\end{array}$} & \multicolumn{2}{|c|}{$\begin{array}{c}\text { Gross Return } \\
\text { (Rs/ha) }\end{array}$} & \multicolumn{2}{|c|}{$\begin{array}{c}\text { Net Return } \\
\text { (Rs/ha) }\end{array}$} & \multicolumn{2}{|c|}{ BC ratio } \\
\cline { 3 - 10 } & DP* & FP** & DP* & FP** & DP* & FP* & DP* & FP** \\
\hline Kharif 2014 & $\begin{array}{l}\text { Palam } \\
\text { Pitambar }\end{array}$ & 62200 & 56200 & 431460 & 287745 & 369260 & 231545 & 6.94 & 5.12 \\
\hline Kharif 2015 & $\begin{array}{l}\text { Palam } \\
\text { Pitambar }\end{array}$ & 85000 & 72000 & 279620 & 197860 & 194620 & 125860 & 3.29 & 2.75 \\
\hline Kharif 2014 & $\begin{array}{l}\text { Palam } \\
\text { Lalima }\end{array}$ & 62200 & 56200 & 385335 & 287745 & 323135 & 231545 & 6.20 & 5.12 \\
\hline Kharif 2015 & $\begin{array}{l}\text { Palam } \\
\text { Lalima }\end{array}$ & 85000 & 72000 & 254650 & 197860 & 169650 & 125860 & 3.00 & 2.75 \\
\hline Pooled data & Average & 73600 & 64100 & 337766 & 242803 & 264166 & 178703 & 4.85 & 3.93 \\
\hline
\end{tabular}

* DP: Demonstration plot; **FP: Farmers plot

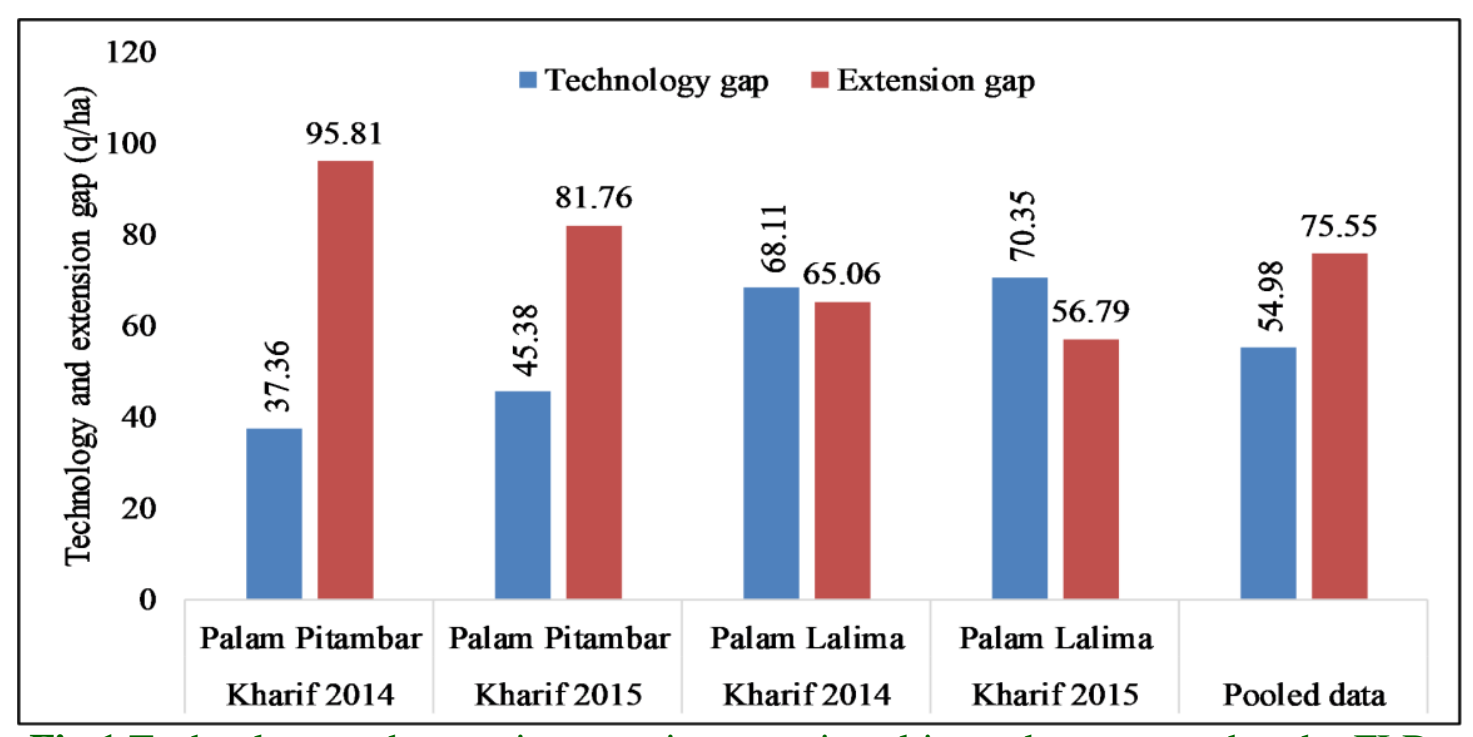

Fig.1 Technology and extension gaps in turmeric cultivars demonstrated under FLDs

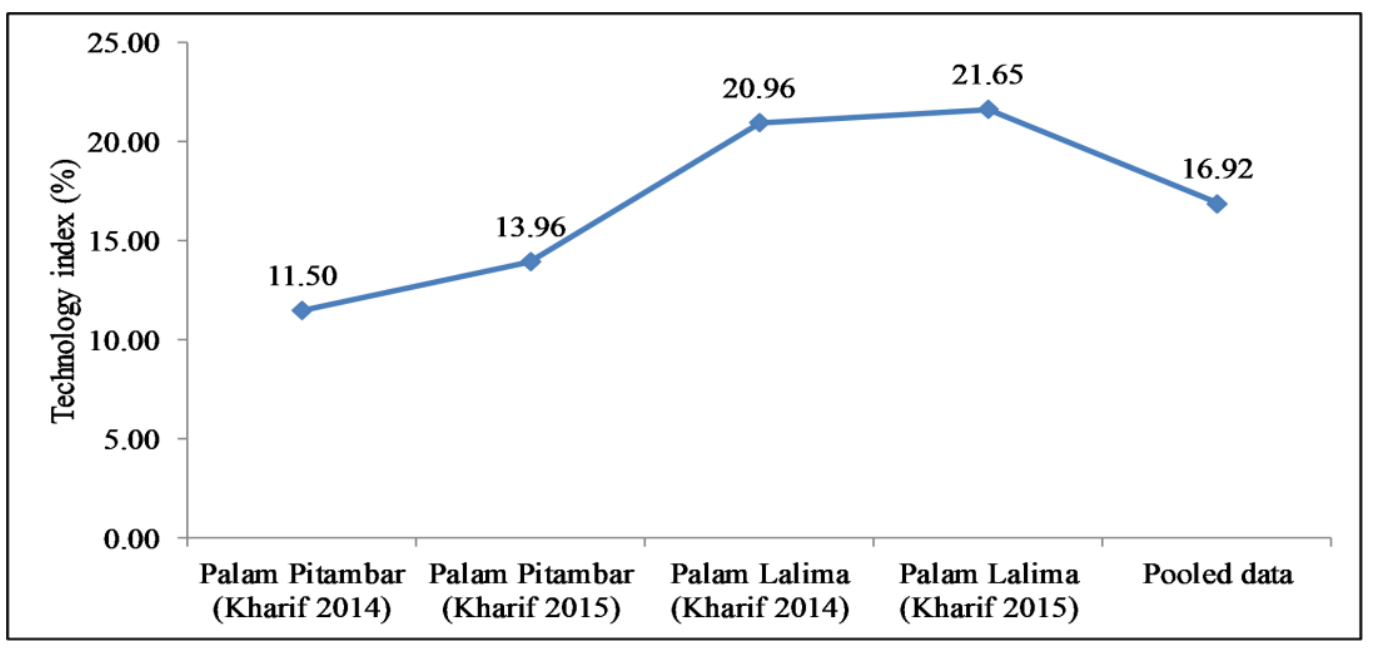

Fig.2 Technology index in turmeric cultivars demonstrated under FLDs 
Overall, a technology index of $16.92 \%$ was observed in pooled data which showed the better performance of FLD's interventions and require concerted efforts by extension personnel of the state department of agriculture to up-scale this technology for larger areas in the state. Dubey et al., (2017) and Kant et al., (2020) also reported the lower value of the technology index under demonstrated technologies in turmeric crop.

The annually harvested both cultivars of turmeric viz. Palam Pitambar and Palam Lalima proved to be superior in terms of productivity and profitability over the farmer's practice. However, some gaps are there, which need to look upon. Technology gaps cannot be narrowed down as these are concerning to environmental factors while extension gaps are manageable and under the control of management factors. Therefore, extension and research programmes should be designed in a way to reduce these yield gaps to further intensify the acreage of annually harvested turmeric cultivars in the region. This crop can also be a better option in those areas where farmers keep their land fallow due to monkey menace.

\section{References}

Anonymous, 2018. Turmeric outlookDecember 2018. Agricultural Market Intelligence Centre, PJTSAU.

Barua, U. and Tripathi, A.K. 2015. Impact of frontline demonstration on yield enhancement of turmeric. Int.J. Farm Sci. 4(4):235-239.

Choudhary, A.K. 2013. Technological and extension yield gaps in pulse crops in Mandi district of Himachal Pradesh, India. Ind. J. Soil Cons.41(1): 88-97.

Choudhary, A.K., Yadav, D.S. and Singh, A. 2009. Technological and extension yield gaps in oilseeds in Mandi district of Himachal Pradesh. Ind. J. Soil Cons.
37(3): 224-229.

Choudhary, B.N. 1999. Krishi Vigyan Kendra-A guide for KVK Managers. Publication Division of Agricultural Extension, ICAR, New Delhi.

Dubey, S., Chandrakar, K., Verma, S.K. and Keshri, R. 2017. Impact of front line demonstration on turmeric in Mahasamund district of Chhattisgarh. Agric. Update. 12(4):732-734.

Kadian, K.S., Sharma, R. and Sharma, A.K. 1997. Evaluation of frontline demonstration trials on oilseeds in Kangra valley of Himachal Pradesh. Ann. Agril. Res.18(1): 40-43.

Kant, K., Ghanshyam., Gupta, S.K.,Pathak, S.K., Patel, A.B., Kumar, S., Kumar, A., Vishwakarma, R. and Sohane, R.K. 2020. Effect of varietal replacement demonstration on the yield and economics of turmeric (Curcuma longa) cv. Rajendra Sonia in Bhagalpur district of Bihar, India. Int. J. Curr. Microbiol. App. Sci. 9(2):1842-1848.

Khan, H.M., Choudhary, A.K. and Rahi, S. 2014. Production technology of turmeric (Curcuma longa L.) In: "Advances in Vegetable Agronomy" (Eds, Anil K. Choudhary, K.S. Rana, AnchalDass and M. Srivastav). Indian Agriculture Research Institute, New Delhi, pp. 198-201.

Kumar, S., Choubey, A.K. and Singh, R. 2015. Analysis of yield gaps in black gram (Vigna mungo) in district of Himachal Pradesh. Him. J. Agril. Res., 41(1):49-54.

Mishra, P.K., Singh, P.N., Singh, S.N. and Kumar, P. 2015. Varietal evaluation of different turmeric (Curcuma longa L.) varieties for Eastern Uttar Pradesh. J. Pharmacogn. Phytochem.4(2):307-310.

Samui, S.K., Maitra, S., Roy, D.K., Mondal, A.K. and Saha, D. 2000. Evaluation of frontline demonstration on groundnut. J. Ind. Soc. Coastal Agric. Res. 18(2): 
180-183.

Singh S.P. and Prasad, R. 2006. Studies on varietal performance of turmeric (Curcuma longa L.) in International $\mathrm{J}$ Plant Sci. 1(1): 22-23.
Yadav, D.S., Sood, P. and Sharma, L.K. 2018. Scaling-up of paddy cv. HPR 2612 (Palam Basmati 1) under irrigated transplanted conditions of Himachal Pradesh. J. Hill Agric. 9(3): 335-339.

\section{How to cite this article:}

Shakuntla Rahi, D. S. Yadav, Pankaj Sood, Kavita Sharma and Sharma, L. K. 2020. Performance of Annually Harvested Improved Turmeric (Curcuma longa L.) Cultivars Grown under Rainfed Conditions. Int.J.Curr.Microbiol.App.Sci. 9(06): 3135-3141.

doi: https://doi.org/10.20546/ijcmas.2020.906.375 